\title{
Soil chemical and physical characteristics as a base for achieving sustainable forest land use in RPH Watugudel, KPH Ngawi, Jawa Timur
}

\author{
Ambar Kusumandari*, Frita Kusumawardani, Seno Adi Subroto, \\ and K. Fajar Wianti
}

Faculty of Forestry, Universitas Gadjah Mada, Jalan Agro No.1, Bulaksumur, Sleman, Caturtunggal, Kabupaten Sleman, Daerah Istimewa Yogyakarta, Indonesia 55281

*e-mail: ambar_kusumandari@ugm.ac.id

\begin{abstract}
This study area was used to be covered by teak forest. However, because of the human influences, the land use was changed to rice field, shrubs, dry field, settlement and remaining teak forest. The aimed of this research is to study the soil chemical and physical characteristics as a base in improving its quality. The soil samples were taken from the field at 5 land use types with 4 repetitions. Then, they were analyzed in the laboratory. This research resulted that all areas have the soil acidity of more than 8 and the soil organic content of $2.72 \%$ to $3.69 \%$, whereas the Nitrogen content varies from $0.2 \%$ to $0.29 \%$. Furthermore, the Phosphorus content varies from $4.61 \mathrm{mg} \cdot \mathrm{L}^{-1}$ to $21.07 \mathrm{mg} \cdot \mathrm{L}^{-1}$. The available potassium ranges from $0.78 \mathrm{cmol} \cdot \mathrm{kg}^{-1}$ to $1.99 \mathrm{cmol} \cdot \mathrm{kg}^{-1}$. The soil physical characteristics of the study area showed that the bulk density varies around $1 \mathrm{Mg} \cdot \mathrm{m}^{-3}$ and the particle density of $2.13 \mathrm{Mg}$. $\mathrm{m}^{-3}$ to $2.27 \mathrm{Mg} \cdot \mathrm{m}^{-3}$. The porosity also varies from $46.30 \%$ to $60.80 \%$, whereas the soil permeability ranges widely from $1.4 \mathrm{~cm} \cdot \mathrm{h}^{-1}$ to 25.9 $\mathrm{cm} \cdot \mathrm{h}^{-1}$. In conclusion, the study area has the high soil acidity, relatively high soil organic matter content, low nitrogen, phosphor and potassium, good porosity and relatively bad permeability. To achieve sustainable forest land use, the use of fertilizer is required, also the implementation of soil tillage is recommended to improve the soil physical characteristics.
\end{abstract}

\section{Keywords}

characteristics, forest, land use, soil, sustainable

Citation: Kusumandari, A., Kusumawardani, F., Subroto, S. A., \& Wianti, K. F. (2018). Soil chemical and physical characteristics as a base for achieving sustainable forest land use in RPH Watugudel, KPH Ngawi, Jawa Timur. In T. R. Nuringtyas, A. C. Sukartiko, \& A. Isnansetyo (Eds.), UGM Digital Press Life Sciences: Vol. 1. Proceeding of the 2nd International Conference on Tropical Agriculture, (pp. 1-6).

Published: October, 2018

\author{
characteristics, forest, land use, soil, sustainable
}

\section{Introduction}

Research of soil characteristics is absolutely important to achieve sustainable forest management. However [1] stated that most of soil properties are time-consuming and costly to measure and also change over time. In this research, both the soil chemical and physical characteristics were studied as a base for sustainable forest land use. The study area of RPH Watugudel, RPH Ngawi, Jawa Timur used to be covered by teak forest. However, this land coverage of land use was 
changed to be rice field, shrubs, cultivated land, settlement and the remaining teak forest. The changes was a result of human influences, which then the soil that was disturbed would have a low fertility. However, the influences of human disturbance to soil characteristic have received limited attention. So, research regarding with this topic is relatively rare.

Teak forest management in Indonesia began at period of Governance of Dutch Colonialism in 1860. After Independence of Indonesia in 1945, teak forest was managed by Department of Forestry and now is managed by Perum Perhutani. During that time, it has been applied various approach of forest management which relate to sustainable principles, but with existence of ecosystem change, there is an indication that teak forest was degraded [2].

It was summarized by [3] that there were 2 effects on soil, include direct effect such as physical disturbance, incorporation of entropic materials, and burial or coverage of soil by fill material and impervious surfaces. Soil management practices such as fertilization and irrigation which are introduced after the initial development disturbance also are considered direct effect. Indirect effect include the urban heat island, soil hydrophobicity, introductions of exotic plant and animal species and atmospheric deposition of pollutants such as $\mathrm{N}$, heavy metals, and potentially toxic organic chemicals.

At the study area (RPH Watugudel), the most influenced effect to the soil was caused by the process of land use change, which was teak forest become other land use types: shrubs, rice field, settlement, cultivated land and remaining teak forest. This change resulted in the variety of vegetation coverage and soil properties, both chemical and physical. The soil management practiced such as fertilization, irrigation, tillage and land burning would effect the soil properties as well.

According to [4] there were six variables, i.e. rainfall, soil type, slope, populations, populations density, and distance to urban area were significantly affecting the land use and cover changes for the watershed. The objective of this research is to study is to study the soil chemical and physical characteristics as a base in improving its quality.

\section{Materials and Methods}

The study area is located in RPH Watugudel, KPH Ngawi, Jawa Timur. The soil type of the area is Grumosol, which has a very high clay content and the very dark color. Five sites were chose to conduct this research: shrubs, rice field, settlement, cultivated land, and remaining teak forest. After overlying the land use map (5 land uses) and slope class map (4 classes), it was resulted 19 land mapping units, so, the soil samples were taken at these 19 locations.

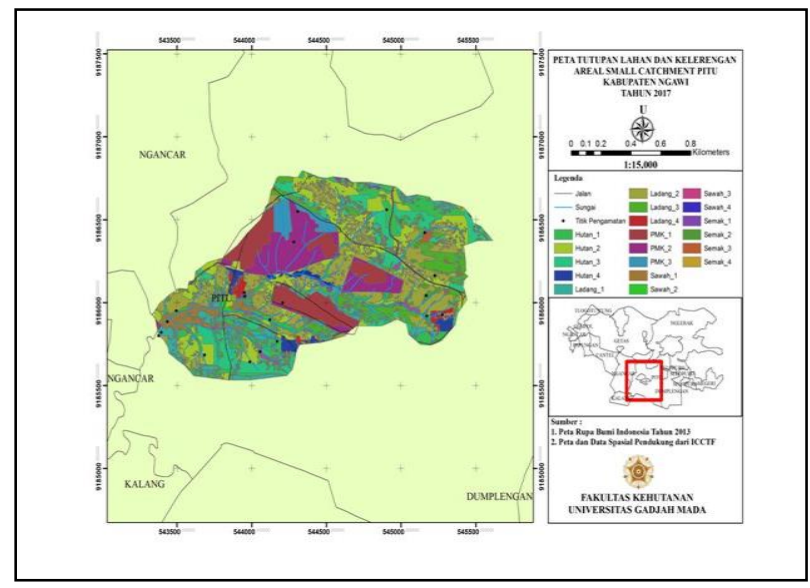

Fig. 1 Land unit map of RPH Watugudel, year 2017

The chemical and physical analysis was performed as follows: soil $\mathrm{pH}$ was measured of a soil solution 1:2.5 in water, and the soil organic content was analyzed by using Walkley and Black method. The total Nitrogen was measured by using titration method. Whereas the total Phosphorus and available Potassium were analyzed by using spectrophotometer. The soil porosity was calculated based on the soil bulk density (BD) and soil specific bulk density (PBD). Finally, the soil permeability was measured in the laboratory by using soil permeameter. 


\section{Results and Discussions}

Table 1 shows the result of the soil laboratory analysis. Then, Table 2 shows the statistical analysis of the whole area.

Table 1 Soil physical and chemical characteristics

\begin{tabular}{|c|c|c|c|c|c|c|c|c|c|c|}
\hline \multirow{2}{*}{ Code } & \multirow{2}{*}{$\begin{array}{c}\mathrm{pH}(1: 5) \\
\mathrm{H} 20\end{array}$} & \multirow{2}{*}{$\begin{array}{l}\text { SOC } \\
(\%)\end{array}$} & \multirow{2}{*}{$\begin{array}{c}\text { Total N } \\
(\%)\end{array}$} & \multirow{2}{*}{$\begin{array}{c}\text { Avail P } \\
\left(\mathrm{mg} \cdot \mathrm{L}^{-1}\right)\end{array}$} & \multirow{2}{*}{$\begin{array}{c}\text { Avail K } \\
\left(\mathrm{cmol} \cdot \mathrm{kg}^{-1}\right)\end{array}$} & $\mathrm{BD}$ & PBD & \multirow{2}{*}{$\begin{array}{c}\text { Porosity } \\
(\%)\end{array}$} & \multicolumn{2}{|c|}{ Permeability } \\
\hline & & & & & & \multicolumn{2}{|c|}{$\left(\mathrm{Mg} \cdot \mathrm{m}^{-3}\right)$} & & $\left(\mathrm{cm} \cdot \mathrm{h}^{-1}\right)$ & Class \\
\hline HTN.1 & 7.83 & 4.29 & 0.25 & 4.32 & 1.00 & 1.08 & 1.99 & 45.80 & 0.28 & Slow \\
\hline HTN.2 & 8.16 & 3.82 & 0.24 & 7.38 & 0.65 & 1.01 & 2.21 & 54.45 & 5.13 & Moderate \\
\hline HTN.3 & 7.96 & 2.43 & 0.16 & 1.21 & 0.63 & 1.34 & 2.29 & 41.35 & 0.01 & Very slow \\
\hline HTN.4 & 8.23 & 4.23 & 0.26 & 5.55 & 0.92 & 1.02 & 2.17 & 53.17 & 0.20 & Slow \\
\hline Average & 8.05 & 3.69 & 0.23 & 4.62 & 0.80 & 1.11 & 2.17 & 48.69 & 1.41 & \\
\hline SWH.1 & 8.23 & 2.43 & 0.17 & 13.19 & 1.05 & 0.94 & 2.17 & 56.74 & 0.01 & Very slow \\
\hline SWH.2 & 8.20 & 2.74 & 0.22 & 32.53 & 0.85 & 0.88 & 2.15 & 58.84 & 14.89 & Rapid \\
\hline SWH.3 & 8.28 & 3.13 & 0.18 & 13.11 & 0.57 & 0.70 & 2.30 & 69.45 & 3.59 & Moderate \\
\hline SWH.4 & 8.27 & 2.58 & 0.24 & 25.47 & 0.66 & 0.95 & 2.27 & 58.20 & 0.07 & Very slow \\
\hline Average & 8.25 & 2.72 & 0.20 & 21.08 & 0.78 & 0.87 & 2.22 & 60.81 & 4.64 & \\
\hline SMK.1 & 7.91 & 3.45 & 0.23 & 26.42 & 0.96 & 1.03 & 2.26 & 54.54 & 18.78 & Rapid \\
\hline SMK.2 & 8.06 & 4.93 & 0.29 & 19.64 & 0.95 & 1.00 & 1.99 & 49.61 & 6.54 & Slightly rapid \\
\hline SMK.3 & 8.05 & 4.23 & 0.29 & 9.24 & 1.03 & 1.01 & 2.16 & 53.11 & 1.80 & Slightly slow \\
\hline SMK.4 & 8.16 & 3.72 & 0.35 & 7.42 & 0.74 & 0.98 & 2.12 & 53.60 & 76.48 & Very rapid \\
\hline Average & 8.05 & 4.08 & 0.29 & 15.68 & 0.92 & 1.01 & 2.13 & 52.72 & 25.90 & \\
\hline LDG.1 & 8.13 & 2.97 & 0.26 & 17.74 & 0.73 & 1.05 & 2.32 & 54.67 & 14.13 & Rapid \\
\hline LDG.2 & 8.18 & 2.61 & 0.25 & 8.85 & 0.86 & 1.01 & 2.16 & 53.35 & 0.01 & Very slow \\
\hline LDG.3 & 8.03 & 4.99 & 0.35 & 23.08 & 0.90 & 1.02 & 2.09 & 51.33 & 0.95 & Slightly slow \\
\hline LDG. 4 & 8.16 & 3.73 & 0.29 & 13.50 & 1.29 & 0.99 & 2.21 & 54.89 & 21.91 & Rapid \\
\hline Average & 8.13 & 3.58 & 0.29 & 15.79 & 0.95 & 1.02 & 2.20 & 53.56 & 9.25 & \\
\hline PMPK.1 & 8.07 & 4.22 & 0.31 & 10.31 & 2.39 & 1.15 & 2.15 & 46.61 & 0.14 & Slow \\
\hline РМРК.2 & 8.13 & 3.77 & 0.24 & 6.32 & 2.40 & 1.24 & 2.14 & 42.01 & 0.02 & Very slow \\
\hline \multirow[t]{2}{*}{ РМРК.3 } & 8.03 & 4.12 & 0.29 & 17.35 & 1.18 & 1.14 & 2.30 & 50.26 & 34.04 & Very rapid \\
\hline & 8.08 & 4.04 & 0.28 & 11.33 & 1.99 & 1.18 & 2.20 & 46.29 & 11.40 & \\
\hline
\end{tabular}


Table 2 The statistical analysis of the data

\begin{tabular}{|c|c|c|c|c|c|c|}
\hline & & Sum of Squares & $\mathrm{df}$ & Mean Square & $\mathrm{F}$ & Sig. \\
\hline \multirow{3}{*}{$\mathrm{pH}$} & Between Groups & 0.111 & 4 & 0.028 & 2.503 & 0.090 \\
\hline & Within Groups & 0.155 & 14 & 0.011 & & \\
\hline & Total & 0.266 & 18 & & & \\
\hline \multirow{3}{*}{ SOC } & Between Groups & 4.638 & 4 & 1.159 & 2.243 & 0.117 \\
\hline & Within Groups & 7.235 & 14 & 0.517 & & \\
\hline & Total & 11.872 & 18 & & & \\
\hline \multirow{3}{*}{ Total N } & Between Groups & 0.025 & 4 & 0.006 & 3.444 & 0.037 \\
\hline & Within Groups & 0.025 & 14 & 0.002 & & \\
\hline & Total & 0.050 & 18 & & & \\
\hline \multirow{3}{*}{ Avail P } & Between Groups & 597.520 & 4 & 149.380 & 2.946 & 0.058 \\
\hline & Within Groups & 709.814 & 14 & 50.701 & & \\
\hline & Total & 1307.333 & 18 & & & \\
\hline \multirow{3}{*}{ Avail $\mathrm{K}$} & Between Groups & 3.297 & 4 & 0.824 & 7.970 & 0.001 \\
\hline & Within Groups & 1.448 & 14 & 0.103 & & \\
\hline & Total & 4.745 & 18 & & & \\
\hline \multirow{3}{*}{ PBD } & Between Groups & 0.019 & 4 & 0.005 & 0.451 & 0.770 \\
\hline & Within Groups & 0.146 & 14 & 0.010 & & \\
\hline & Total & 0.165 & 18 & & & \\
\hline \multirow{3}{*}{ Porosity } & Between Groups & 453.238 & 4 & 113.309 & 5.800 & 0.006 \\
\hline & Within Groups & 273.494 & 14 & 19.535 & & \\
\hline & Total & 726.731 & 18 & & & \\
\hline \multirow{3}{*}{ Permeability } & Between Groups & 1425.540 & 4 & 356.385 & 1.031 & 0.425 \\
\hline & Within Groups & 4838.896 & 14 & 345.635 & & \\
\hline & Total & 6264.436 & 18 & & & \\
\hline \multirow{3}{*}{$\mathrm{BD}$} & Between Groups & 0.200 & 4 & 0.050 & 5.780 & 0.006 \\
\hline & Within Groups & 0.121 & 14 & 0.009 & & \\
\hline & Total & 0.322 & 18 & & & \\
\hline
\end{tabular}

\subsection{Soil Acidity}

Soil acidity has a very close relationship with the soil fertility. The best soil acidity for plant to grow is about neutral. The lower and the higher than neutral will be worse for plant growing. This situation is a result of the nutrient availability in the soil. Almost all of the nutrient content are in a good availability when they are in the neutral soil $\mathrm{pH}$. In this study, the average soil $\mathrm{pH}$ were varies from 7.83 to 8.23 . The highest average soil $\mathrm{pH}$ can be found in the rice field (8.25) and the lowest was in the forest area (8.025). At the rice field, the farmers use the fertilizer so that increase the soil $\mathrm{pH}$ compare to the forest area which has lack fertilizer result in the lower $\mathrm{pH}$.

\subsection{Soil Organic Content}

Soil organic carbon maintains soil health and productivity of plant resources [5]. At least there are two advantages of the existence of soil organic matter in the soil that are: increasing the water absorbance and the soil aggregate stability. Research done by [6] showed that the coefficient correlation for the relationship between aggregate stability and organic matter content was highly significant $(\mathrm{P}<0.01 \%)$ which is in agreement with the findings of [7]. Furthermore, the soil organic matter is driven by the soil texture [8]. 
The highest soil organic content was in the shrubs area $(3.69 \%)$ and the lowest was in the rice field $(2.72 \%)$. According to [9] the intensive cultivation causes the decreasing of organic carbon. This research has the same findings. Where the cultivation in rice field area is much more intensive than that of the shrubs area. The research finding resulted by [2] shows that forest soil is a source of organic matter that required for improving soil fertility and productivity, includes soil structure, cation exchange capacity (CEC), and source of Nitrogen and other nutrients and as an energy for soil microbial. In more detail, it was studied by [10] that total carbon stocks did not differ significantly between the soil types, but they differ among land use classes.

\subsection{Nitrogen, Phosphorus, and Potassium Content}

The Nitrogen $(\mathrm{N})$ content were ranging from $0.16 \%$ to $0.35 \%$. The highest average of $\mathrm{N}$ content was in the shrubs area $(0.29 \%)$. whereas the lowest average was in the rice field $(0.20 \%)$. At the shrubs area, the input $\mathrm{N}$ comes from the fallen barks, leaves, fruits and others. Which they decomposed and there is no harvesting. But on the other hand, at the rice field, the uptake of the $\mathrm{N}$ goes faster and the harvesting process also takes away the $\mathrm{N}$ from the soil.

The phosphorus (P) content of the rice field was the highest $\left(21.07 \mathrm{mg} \cdot \mathrm{L}^{-1}\right)$, whereas at the forest area was the lowest $\left(4.61 \mathrm{mg} \cdot \mathrm{L}^{-1}\right.$ ). The $\mathrm{P}$ in the soil is influenced by the soil $\mathrm{pH}$. The higher $\mathrm{P}$ at the rice field is caused by the input technology of fertilizer that was added into the soil. By contrary at the forest area they have to fulfil the P requirement by their own. At this case, almost no fertilizer was added to the soil.

The potassium content at the settlement is the highest $\left(1.99 \mathrm{cmol} \cdot \mathrm{kg}^{-1}\right)$ and the lowest is in the rice field $\left(0.78 \mathrm{cmol} \cdot \mathrm{kg}^{-1}\right)$. At the rice field, the potassium mostly is leached to the lower soil layer as a result of the soil tillage activities. This process is quite often happened at the clay soil. Clay soil has an active layer, where the potassium can be absorbed, so that the available $\mathrm{K}$ is relatively low.

The NPK content of the 20 years old teak forest or older is relatively constant as a result of the litter resulted at its area that can replace the NPK lost from the ecosystem [2].

\subsection{Soil Porosity and Permeability}

The soil porosity was calculated by dividing the soil Bulk density (BD) with the soil particle density times 100 percent. The average bulk density varies from $0.87 \mathrm{Mg} \cdot \mathrm{m}^{-3}$ (at the rice field) to 1.18 at the shrubs area. The particle density varies from $2.13 \mathrm{~cm}^{3}$ (at the shrubs area) to $2.20 \mathrm{~cm}^{3}$ (at the rice field area). The porosity also varies from $46.30 \%$ (at settlement area) to $60.80 \%$ (at the rice field area). This finding supports the earlier work by [11] who reported inverse relationship between bulk density and porosity of the soil.

Soil permeability is the capacity of a porous material to allow fluids through it. It depends on the soil structure, texture, organic matter content and porosity. The highest average soil permeability was in shrubs area $\left(25.9 \mathrm{~cm} \cdot \mathrm{h}^{-1}\right)$ followed by cultivated land, rice field, and forest $\left(1.4 \mathrm{~cm} \cdot \mathrm{h}^{-1}\right)$. The high soil permeability at the shrubs area is a result of the less soil disturbance, by contrary, at the forest area the disturbance is higher and the farmer burns the teak forest soil. So, the forest soil became more compact as showed by the soil bulk density of the forest soil is the second highest $\left(1.1 \mathrm{Mg} \cdot \mathrm{m}^{-3}\right)$.

\subsection{Statistical Analysis}

Table 2 shows that among the 8 soil characteristics, 4 parameters have significant value less than 0.05 , which are: total N, available K, porosity, and bulk density. However, the other 5 parameters that are soil $\mathrm{pH}$, SOC, available P, PBD and permeability are not significantly different between groups. 


\section{Conclusions}

Based on the research result, it can be concluded that the study area has the high soil acidity, relatively high soil organic matter content, low nitrogen, phosphor and potassium, good porosity and relatively bad permeability. To achieve sustainable forest land use, the use of fertilizer is recommended, also the proper soil tillage to improve the soil physical characteristics would be appropriate to be applied in the study area.

Acknowledgement We would like to thank to the 2017 BOPTN project of the Faculty of Forestry, Universitas Gadjah Mada, for the funding. Also special thanks to the students, Ihwanudin, Hela Imbang, Aldo, Inda, and Seto, who helped in the collecting of soil samples from the field and data analysis.

\section{References}

1. Minasny, B., Hartemink, A.E.: Predicting soil properties in the tropics. Earth Science Reviews 106(1), 52-62 (2011). doi: 10.1016/j.earscirev.2011.01.005

2. Didjajani, B.W.: Kehilangan hara akibat erosi (Studi kasus di Tegakan Jati) [Nutrient loss caused by erosion (A Case Study in Teak Forest)]. Agrovigor 5(1), 58-65 (2012). [In Bahasa Indonesia].

3. Pouyat, R.V., Yesilonis, I., Russell-Anelli, J., Noerchal, N.K.: Soil chemical and physical properties that differentiate urban land use and cover types. Soil Science of America Journal 71(3), 1010-1019 (2007).

4. Aroengbinang, B.W., Kaswanto, L.R.: Driving force analysis of land use and cover change in Cimandiri and Cibumi watersheds. Procedia Environmental Sciences 24, 184-188 (2015). doi: 10.1016/j.proenv.2015.03.024

5. Ramifehiarivo, N., Brossard, M., Grinand, C., Andriamananjara, A., Razafimbelo, T., Rasolohery, A., Razafimahatratra, H.: Mapping soil organic carbon on a national scale: Towards an improved and updated map of Madagascar. Geoderma Regional 8, 29-38 (2017). doi: 10.1016/j.geodrs.2016.12.002

6. Aziz, S.A., Karim, S.M.: The effect of some soil physical and chemical properties on aggregate stability in different location in Sulaimana and Halabja governorate. Open Journal of Soil Science 16(4), 81-88 (2016). doi: 10.4236/ojss.2016.64009

7. Chaney, K., Swift, R.S.: The influence of organic matter on aggregate stability in some British soils. Journal of Soil Science 35(2), 223-230 (1984). doi: 10.1111/j.1365-2389.1984.tb00278.x

8. Poggio, L., Gimona, L.: 3D mapping of soil texture in Scotland. Geoderma Regional 9, 5-16 (2017). doi: 10.1016/j.geodrs.2016.11.003.

9. Mukhlis, Nasution, Z., Mulyanto, B.: Effect of land use on the physico-chemical properties of andisols in Mt. Sinabung, North Sumatera, Indonesia. Malaysian Journal of Soil Science 18, 51-60 (2014).

10. Natalia, D., Arisoesilaningsih, E., Hairiah, K.: Are high carbon stocks in agroforests and forest associated with high plant species diversity? Agrivita Journal of Agricultural Science 39(1), 74-82 (2017). doi: 10.17503/agrivita.v39i1.676

11. Arévalo-Gardini, E., Canto, M., Alegre, J., Loli, O., Juica, A., Baligar, V.: Changes in soil physical and chemical properties in long term improved natural and traditional agroforestry management system of cacao genotypes in Peruvian Amazon. PLOS ONE 10(8), e0136784 (2015). doi: 10.1371/journal.pone.0132147 